\title{
Management of Eucalyptus short-rotation coppice and its outcome on fuel quality
}

\author{
Humberto de Jesus Eufrade-Junior*, Saulo Philipe Sebastião Guerra, \\ Cláudio Angeli Sansígolo, Adriano Wagner Ballarin
}

School of Agricultural Sciences, São Paulo State University, UNESP, Botucatu, 18610307, Brazil

\section{A R T I C L E I N F O}

\section{Article history:}

Received 10 August 2017

Received in revised form

20 November 2017

Accepted 12 January 2018

\section{Keywords:}

Thermochemical properties

Biomass

Energy crops

Short rotation coppice

Bioenergy

\begin{abstract}
A B S T R A C T
Earlier experiments with young Eucalyptus short-rotation coppice (SRC) in tropical environment have not evaluated the quality of whole-tree biomass fractions, and as such their total energy potential is still unknown. As this system is managed with a higher planting density and fertilization level compared to conventional plantations, the quality of forest biomass needs to be assessed. Hence, the goal of this study was to analyze how the short-rotation coppice affected the quality of stem, branches, and leaves used for power generation. Samples were collected from high-density plantation of Eucalyptus at two years old, and the thermochemical properties were evaluated. Carbon and ash content were lower for the stem fraction in higher density of planting, although the higher heating value was not significantly different from each treatment. Overall, the fuel quality of whole-forest biomass was not influenced by management practices. Statistically significant differences were found only between the whole-tree fractions. Eucalyptus SRC provided biomass qualitatively close to that from conventional forest systems and has potential to be quickly and feasible energy option.
\end{abstract}

(C) 2018 Elsevier Ltd. All rights reserved.

\section{Introduction}

Biomass feedstock is a pathway to achieve a low carbon footprint in the future [1,2]. Perennial bioenergy crops appear to be important players for developing sustainable land use [3].

Solid biomass be combusted directly in boilers to produce heat and electricity or used to provide derived fuels from thermochemical processes (viz., pyrolysis, gasification, and liquefaction) [4] or as bio-oil [5]. With respect to biomass use in power generation, knowledge about their composition and properties as well as environmentally safe handling are necessary $[6,7]$.

Considerable variation is seen in the elemental, immediate, structural, and chemical composition of the biomass (agricultural and forest crops) types [8-10]. These variations have notable impact on each step of the whole supply chain, such as handling of raw materials, transportation, drying, storage, and the design of the power conversion systems [11]. Moreover, thermochemical

\footnotetext{
* Corresponding author.

E-mail addresses: hdjejunior@gmail.com (H.J. Eufrade-Junior), ssguerra@fca. unesp.br (S.P.S. Guerra), sansigolo@fca.unesp.br (C.A. Sansígolo), awballarin@fca. unesp.br (A.W. Ballarin).
}

properties are very important in ranking the best resources for power generation [12,13].

High-density energy wood plantation has been regarded as a renewable resource worldwide. Studies have been conducted on Salix and Populus species managed in SRC in Europe [14,15]. In South America, especially in Brazil, Eucalyptus species have been used for SRC management [16], as these plantations provide a high productivity in a small planting area, about $19 \mathrm{t}_{\text {dry matter ha }}{ }^{-1}$ year $^{-1}$ with harvesting cycles of two to three years [17]. Whole-tree biomass from SRC is harvested and chipped simultaneously by a modified forager and transported to thermal power plants [18].

Some doubts remain about the effect of this management system on the fuel quality (proximate and elemental chemical composition) of such young material. For Populus species, Monedero et al. [13] observed that planting density had a more significant effect on combustion properties than site characteristics (such as soil properties).

Recent experiments with young Eucalyptus SRC in a tropical environment $[14,15]$ did not evaluate the quality of whole-tree biomass fractions (stem, branches, and leaves), and very little is known about its energy potential. Hence, the goals of this study were: (1) to determine the thermochemical properties of Eucalyptus SRC for bioenergy purposes, and (2) the effect of different 
planting densities and fertilization regimes on whole-tree biomass.

\section{Materials and methods}

\subsection{Sampling and material preparation}

This work was carried out at Botucatu $\left(22^{\circ} 53^{\prime} 09^{\prime \prime} \mathrm{S}\right.$ and $48^{\circ} 26^{\prime}$ $42^{\prime \prime}$ W) in São Paulo state of Brazil. The local area has an average altitude of $872 \mathrm{~m}$ a.s.l., a mean annual precipitation of about $1428 \mathrm{~mm}_{\text {year }}{ }^{-1}$, and an annual average temperature of $20^{\circ} \mathrm{C}$.

Plantations of interspecific hybrid clone, Eucalyptus urophylla $\times$ Eucalyptus grandis were established for two years, each with high, but different, planting densities and fertilization regimes. Plots ( $450 \mathrm{~m}^{2}$ each) had two different spacing modules: $2.8 \times 0.5 \mathrm{~m}\left(7142\right.$ trees hectare $\left.{ }^{-1}\right)$ and $2.8 \times 1.5 \mathrm{~m}$ (2380 trees hectare $^{-1}$ ). Table 1 shows the two different fertilization regimes in which dose 1 corresponds to one-quarter of dose 2 (the conventional dose).

Two years after planting, the diameter at breast height (DBH) and height of all trees on the plots, as well as of randomly selected four mean tree samples per treatment were measured. Each tree was divided into three fractions: stem, branches, and leaves, and a composite sample was used for each biomass fraction. The branches and leaves of the trees were removed. Then, five discs were collected at the following positions along the stem: $0 \%, 25 \%$, $50 \%, 75 \%$, and $100 \%$ of total stem height according to the method described by Ref. [19].

For the fuel quality analysis, an experimental design of completely randomized blocks with 2 spacing density $\times 2$ fertilization regimes $\times 3$ biomass fractions $\times 3$ repetitions was finalized.

\subsection{Laboratory procedures and properties}

Forest biomass was sawed in Wiley type mill followed by sifting in 40-60 mesh screens. The thermochemical properties were determined according to standard methods (see Table 2).

Ultimate composition (CHNS) was obtained at elemental analyzer model 2400 Parkin Elmer by modified Pregl-Dumas method. Then, oxygen content was determined as the balance out of $100 \%$ [20].

\subsection{Statistical analysis}

Data normality was assessed by Shapiro-Wilk's test $(\mathrm{p}<.05)$. The effect of density planting (D), fertilization level (F), and biomass fraction (B) on thermochemical properties of Eucalyptus SRC was evaluated by ANOVA complemented by Tukey's test $(\mathrm{p}<.05)$. Biomass fraction was taken into account as the whole-tree biomass was used for bioenergy purposes [26,27].

Table 1

Description of the fertilization regimes.

\begin{tabular}{lllll}
\hline Fertilizing levels & Days after planting & Dose 1 & Dose 2 \\
Fertilizer & & g plant $^{-1}$ \\
\hline NPK (6-30-10) & 0 & 35.0 & 140 \\
NPK (19-00-19) + B (0.7\%) e Zn (3\%) & 180 & 27.5 & 110 \\
NPK (19-00-19) + B (0.7\%) e Zn (3\%) & 360 & 27.5 & 110 \\
\hline
\end{tabular}

Table 2

Summary of standards and methods used to assess the forest biomass properties.

\begin{tabular}{lll}
\hline Properties & Initials & Standards and methods \\
\hline Carbon, hydrogen, nitrogen, sulfur & $\mathrm{CHNS}$ & Pregl-Dumas method \\
Oxygen & $\mathrm{O}$ & {$[20]$} \\
Ash & $\mathrm{A}$ & {$[21]$} \\
Fixed carbon & $\mathrm{FC}$ & {$[20]$} \\
Volatile matter & $\mathrm{VM}$ & {$[22]$} \\
Holocellulose & $\mathrm{HC}$ & Delignification using $\mathrm{NaClO}_{2}$ \\
Acid-insoluble lignin & $\mathrm{L}$ & {$[23]$} \\
Total extractives & $\mathrm{E}$ & {$[24]$} \\
Higher Heating Value & $\mathrm{HHV}$ & {$[25]$} \\
\hline
\end{tabular}

\section{Results and discussion}

\subsection{Fuel quality of whole-biomass of Eucalyptus SRC for bioenergy} use

All treatments were statistically different among biomass fractions-stem, branches, and leaves (Table 3), and larger differences were observed between woody fractions and leaves.

Leaf biomass had higher hydrogen and carbon content than other fractions, which contributed to more energy released on combustion. Positive correlation has been observed between the amount of these elements and the calorific value of the biomass [28]. However, the leaves have a higher amount of nitrogen and sulfur which can damage the environment due to emissions of their ozone-depleting oxides [29]. Results above the limiting content of $0.6 \%$ and $0.2 \%$ for $\mathrm{N}$ and $\mathrm{S}$, respectively, can induce emission problems [30].

Further, the $\mathrm{C} / \mathrm{N}$ ratio was higher for woody fractions (104 and 120 for branches and stem, respectively) than leaves (28). Greater $\mathrm{C} / \mathrm{N}$ ratio implies a lower decomposition rate when the biomass is left on the field after harvesting for reduction of moisture content and, consequently, energy content is slightly affected.

For proximate analysis, the stem fraction showed greater volatile matter, which contributes to the ignition of biomass, and the leaves fraction had a higher fixed carbon content, which increases its burning period in the boiler [12]. High results of ash content for leaves mean the trees could be defoliated before use.

Levels of acid-insoluble lignin and total extractives in the stem are similar to those reported by Ref. [8] and are statistically different for the leaves fraction. Among the biomass fractions, lignin content was similar for the stem and branches.

Energy of combustion varies considerably with the chemical composition. Compounds such as resin, tannins, lignin, terpenes, and waxes have high energy values whereas carbohydrates have

Table 3

Effect of biomass fraction on thermochemical properties of Eucalyptus grandis $\times E$. urophylla at 2 years old grown on short rotation forest.

\begin{tabular}{lllll}
\hline Properties & Unit & Stem & Branches & Leaves \\
\hline Carbon & wt\% (d.b.) & $44.3 \pm 0.5 \mathrm{~b}$ & $44.7 \pm 0.5 \mathrm{~b}$ & $49.1 \pm 0.6 \mathrm{a}$ \\
Hydrogen & wt\% (d.b.) & $7.4 \pm 0.5 \mathrm{~b}$ & $7.5 \pm 0.3 \mathrm{~b}$ & $8.2 \pm 0.3 \mathrm{a}$ \\
Oxygen & wt\% (d.b.) & $46.7 \pm 1.0 \mathrm{a}$ & $45.8 \pm 0.8 \mathrm{~b}$ & $37.5 \pm 0.8 \mathrm{c}$ \\
Nitrogen & wt\% (d.b.) & $0.37 \pm 0.1 \mathrm{c}$ & $0.43 \pm 0.1 \mathrm{~b}$ & $2.0 \pm 0.3 \mathrm{a}$ \\
Sulfur & wt\% (d.b.) & $0.09 \pm 0.0 \mathrm{~b}$ & $0.10 \pm 0.0 \mathrm{~b}$ & $0.13 \pm 0.0 \mathrm{a}$ \\
Ash & wt\% (d.b.) & $1.1 \pm 0.2 \mathrm{c}$ & $1.5 \pm 0.3 \mathrm{~b}$ & $3.1 \pm 0.6 \mathrm{a}$ \\
Fixed carbon & wt\% (d.b.) & $14.4 \pm 1.2 \mathrm{c}$ & $17.3 \pm 1.0 \mathrm{~b}$ & $18.4 \pm 0.6 \mathrm{a}$ \\
Volatile matter & wt\% (d.b.) & $84.5 \pm 1.3 \mathrm{a}$ & $81.2 \pm 1.1 \mathrm{~b}$ & $78.5 \pm 0.7 \mathrm{c}$ \\
Holocellulose & wt\% (d.b.) & $81.5 \pm 1.5 \mathrm{a}$ & $68.4 \pm 2.1 \mathrm{~b}$ & $34.9 \pm 1.9 \mathrm{c}$ \\
Acid-insoluble lignin & wt\% (d.b.) & $21.6 \pm 0.8 \mathrm{a}$ & $20.7 \pm 0.9 \mathrm{ab}$ & $20.2 \pm 2.7 \mathrm{~b}$ \\
Total extractives & wt\% (d.b.) & $2.0 \pm 0.8 \mathrm{c}$ & $12.4 \pm 1.2 \mathrm{~b}$ & $37.9 \pm 1.3 \mathrm{a}$ \\
Higher Heating Value & MJ kg ${ }^{-1}$ & $18.9 \pm 0.3 \mathrm{c}$ & $19.2 \pm 0.3 \mathrm{~b}$ & $22.0 \pm 0.2 \mathrm{a}$ \\
\hline
\end{tabular}

The means that do not differ from each other at the 0.05 significance level by Tukey's test are marked with the same letters in the same line. 
relatively low values [31]. Leaves showed high total extractives content so that their heating values (HHV) were higher than for woody fractions.

Results found were similar than those reported for conventional plantations in Brazil [12]. It showed the potential of these energy crops to provide a high-quality raw material within a short time, say two to three years after planting.

\subsection{Effect of planting density and fertilization level on thermochemical properties}

The thermochemical properties of forest biomass grown on SRC are shown in Table 4. These results were complemented by the analysis of variance, which showed the effect of density planting (D), biomass fraction (B), and fertilization level (F) in the treatments (Table 5).

Results indicated double and triple interactions among the variation factors (D, F, B). It is clear from Table 3 that biomass fraction had a significant effect on all thermochemical properties.

\subsubsection{Ultimate analysis}

Carbon content was higher for lower planting density and higher fertilization level as shown in Table 6. As discussed earlier, carbon content has a positive effect during combustion and contributes to enhance energy potential.

Increased density of planting on Eucalyptus SRC provided higher biomass yield per hectare [17] and probably more carbon sequestration from the atmosphere, but there is less allocation of $C$ by unit of mass. Hence, the higher density planting and lower fertilization level suggest a reduction of carbon dioxide emissions on combustion of these energy crops.

Nitrogen and oxygen showed a triple interaction for variance factors (Fig. 1). Nitrogen content on leaves showed a positive trend with increased density of planting irrespective of fertilization level. For woody fractions, the increase in $\mathrm{N}$ content did not reach the limiting level to cause emission problems $(0.6 \%)$ as reported by

Table 4

Thermochemical properties of forest biomass from short rotation coppice of Eucalyptus grandis $\times$ E. urophylla at 2 years old.

\begin{tabular}{|c|c|c|c|c|c|}
\hline \multirow[t]{2}{*}{ Properties } & \multirow{2}{*}{$\frac{\text { Spacing }(\mathrm{m})}{\text { Fertilization }}$} & \multirow{2}{*}{$\frac{2.8 \times 0.5}{\text { Level } 1}$} & \multirow{2}{*}{$\frac{2.8 \times 0.5}{\text { Level } 2}$} & \multirow{2}{*}{$\frac{2.8 \times 1.5}{\text { Level } 1}$} & \multirow{2}{*}{$\frac{2.8 \times 1.5}{\text { Level } 2}$} \\
\hline & & & & & \\
\hline \multirow[t]{3}{*}{ Carbon (\%) } & Stem & $43.9 \pm 0.3$ & $43.9 \pm 0.4$ & $44.7 \pm 0.1$ & $44.8 \pm 0.2$ \\
\hline & Branches & $44.6 \pm 0.2$ & $44.6 \pm 0.3$ & $44.4 \pm 0.9$ & $45.0 \pm 0.2$ \\
\hline & Leaves & $48.9 \pm 0.4$ & $49.1 \pm 0.1$ & $48.7 \pm 0.8$ & $49.7 \pm 0.7$ \\
\hline \multirow[t]{3}{*}{ Hydrogen (\%) } & Stem & $7.1 \pm 0.6$ & $7.4 \pm 0.5$ & $7.7 \pm 0.4$ & $7.5 \pm 0.5$ \\
\hline & Branches & $7.5 \pm 0.1$ & $7.8 \pm 0.1$ & $7.2 \pm 0.4$ & $7.6 \pm 0.1$ \\
\hline & Leaves & $8.2 \pm 0.2$ & $8.4 \pm 0.0$ & $8.2 \pm 0.1$ & $8.1 \pm 0.5$ \\
\hline \multirow[t]{3}{*}{ Oxygen (\%) } & Stem & $47.5 \pm 1.0$ & $47.2 \pm 0.8$ & $45.8 \pm 0.3$ & $46.2 \pm 0.6$ \\
\hline & Branches & $45.4 \pm 0.5$ & $45.8 \pm 0.3$ & $46.7 \pm 1.1$ & $45.2 \pm 0.2$ \\
\hline & Leaves & $37.5 \pm 0.6$ & $36.6 \pm 0.4$ & $37.8 \pm 0.5$ & $37.8 \pm 1.2$ \\
\hline \multirow[t]{3}{*}{ Nitrogen (\%) } & Stem & $0.5 \pm 0.0$ & $0.4 \pm 0.1$ & $0.3 \pm 0.0$ & $0.2 \pm 0.0$ \\
\hline & Branches & $0.6 \pm 0.0$ & $0.5 \pm 0.0$ & $0.4 \pm 0.1$ & $0.3 \pm 0.1$ \\
\hline & Leaves & $2.4 \pm 0.0$ & $2.1 \pm 0.1$ & $1.6 \pm 0.1$ & $1.8 \pm 0.1$ \\
\hline \multirow[t]{3}{*}{ Sulfur (\%) } & Stem & $0.09 \pm 0.0$ & $0.09 \pm 0.0$ & $0.10 \pm 0.0$ & $0.09 \pm 0.0$ \\
\hline & Branches & $0.10 \pm 0.0$ & $0.10 \pm 0.0$ & $0.10 \pm 0.0$ & $0.09 \pm 0.0$ \\
\hline & Leaves & $0.14 \pm 0.0$ & $0.14 \pm 0.0$ & $0.13 \pm 0.0$ & $0.14 \pm 0.0$ \\
\hline \multirow[t]{3}{*}{ Ash (\%) } & Stem & $0.86 \pm 0.1$ & $0.94 \pm 0.1$ & $1.39 \pm 0.2$ & $1.18 \pm 0.2$ \\
\hline & Branches & $1.73 \pm 0.2$ & $1.22 \pm 0.1$ & $1.23 \pm 0.1$ & $1.79 \pm 0.2$ \\
\hline & Leaves & $2.77 \pm 0.1$ & $3.62 \pm 0.2$ & $3.55 \pm 0.3$ & $2.44 \pm 0.1$ \\
\hline \multirow[t]{3}{*}{ Fixed carbon (\%) } & Stem & $14.3 \pm 1.2$ & $13.2 \pm 1.2$ & $15.0 \pm 0.6$ & $15.0 \pm 1.3$ \\
\hline & Branches & $16.7 \pm 0.6$ & $16.6 \pm 1.2$ & $17.4 \pm 0.6$ & $18.4 \pm 1.3$ \\
\hline & Leaves & $18.5 \pm 0.5$ & $17.8 \pm 0.4$ & $18.5 \pm 0.6$ & $18.7 \pm 0.9$ \\
\hline \multirow[t]{3}{*}{ Volatile matter (\%) } & Stem & $84.8 \pm 1.1$ & $85.9 \pm 1.2$ & $83.6 \pm 0.5$ & $83.8 \pm 1.3$ \\
\hline & Branches & $81.6 \pm 0.5$ & $82.2 \pm 0.8$ & $81.4 \pm 0.9$ & $79.8 \pm 0.4$ \\
\hline & Leaves & $78.8 \pm 0.5$ & $78.6 \pm 0.6$ & $77.9 \pm 0.5$ & $78.9 \pm 0.9$ \\
\hline \multirow[t]{3}{*}{ Holocellulose (\%) } & Stem & $83.1 \pm 0.5$ & $81.8 \pm 1.2$ & $80.6 \pm 0.4$ & $80.6 \pm 1.8$ \\
\hline & Branches & $70.3 \pm 0.3$ & $69.4 \pm 0.1$ & $67.2 \pm 2.8$ & $66.9 \pm 2.2$ \\
\hline & Leaves & $34.6 \pm 0.3$ & $33.0 \pm 0.4$ & $35.3 \pm 1.6$ & $36.7 \pm 2.3$ \\
\hline \multirow[t]{3}{*}{ Acid-insoluble lignin (\%) } & Stem & $21.7 \pm 0.4$ & $21.2 \pm 0.4$ & $22.4 \pm 0.3$ & $20.9 \pm 1.3$ \\
\hline & Branches & $20.8 \pm 0.6$ & $21.0 \pm 0.2$ & $21.3 \pm 0.3$ & $19.8 \pm 1.4$ \\
\hline & Leaves & $17.9 \pm 1.4$ & $18.4 \pm 2.2$ & $21.7 \pm 1.9$ & $22.8 \pm 1.8$ \\
\hline \multirow[t]{3}{*}{ Total extractives (\%) } & Stem & $2.1 \pm 1.0$ & $2.7 \pm 0.2$ & $1.5 \pm 0.7$ & $1.6 \pm 0.4$ \\
\hline & Branches & $11.2 \pm 1.0$ & $12.4 \pm 0.3$ & $13.0 \pm 1.0$ & $12.9 \pm 1.6$ \\
\hline & Leaves & $38.4 \pm 1.2$ & $37.5 \pm 0.8$ & $37.6 \pm 1.3$ & $38.2 \pm 2.2$ \\
\hline \multirow[t]{3}{*}{ Higher Heating Value $\left(\mathrm{MJ} \mathrm{kg}^{-1}\right)$} & Stem & $18.6 \pm 0.3$ & $18.9 \pm 0.1$ & $19.1 \pm 0.2$ & $19.0 \pm 0.2$ \\
\hline & Branches & $19.3 \pm 0.2$ & $19.2 \pm 0.3$ & $19.1 \pm 0.1$ & $19.3 \pm 0.4$ \\
\hline & Leaves & $22.2 \pm 0.1$ & $21.9 \pm 0.1$ & $21.8 \pm 0.1$ & $22.2 \pm 0.1$ \\
\hline
\end{tabular}


Table 5

P-values of analysis of variance (ANOVA) for factors - density planting, biomass fraction and fertilization level on chemical properties of Eucalyptus SRC at 2 years old.

\begin{tabular}{|c|c|c|c|c|c|c|c|}
\hline Properties & $\mathrm{D}$ & $\mathrm{F}$ & B & $\mathrm{D} \times \mathrm{F}$ & $\mathrm{D} \times \mathrm{B}$ & $\mathrm{F} \times \mathrm{B}$ & $\mathrm{D} \times \mathrm{F} \times \mathrm{B}$ \\
\hline Carbon & $0.019^{*}$ & $0.042^{*}$ & $0.000^{* *}$ & 0.086 & 0.097 & 0.326 & 0.587 \\
\hline Hydrogen & 0.916 & 0.261 & $0.000^{* *}$ & 0.456 & 0.102 & 0.548 & 0.536 \\
\hline Oxygen & 0.687 & 0.199 & $0.000^{* *}$ & 0.883 & $0.003^{* *}$ & 0.541 & $0.040^{*}$ \\
\hline Nitrogen & $0.000^{* *}$ & $0.000^{* *}$ & $0.000^{* *}$ & $0.004^{* *}$ & $0.000^{* *}$ & 0.472 & $0.000^{* *}$ \\
\hline Sulfur & 0.235 & 0.625 & $0.000^{* *}$ & 0.914 & 0725 & 0.305 & 0.452 \\
\hline Ash & 0.212 & 0.321 & $0.000^{* *}$ & $0.002^{*}$ & $0.001^{* *}$ & 0.540 & $0.000^{* *}$ \\
\hline Fixed carbon & $0.001^{* *}$ & 0.700 & $0.000^{* *}$ & 0.080 & 0.409 & 0.335 & 0.958 \\
\hline Volatile matter & $0.001^{* *}$ & 0.547 & $0.000^{* *}$ & 0.258 & 0.123 & 0.243 & 0.060 \\
\hline Holocellulose & 0.119 & 0.346 & $0.000^{* *}$ & 0.101 & $0.001^{* *}$ & 0.876 & 0.602 \\
\hline Acid-insoluble lignin & $0.004^{* *}$ & 0.515 & $0.034^{*}$ & 0.393 & $0.000^{* *}$ & 0.183 & 0.554 \\
\hline Total extractives & 0.847 & 0.481 & $0.000^{* *}$ & 0.849 & 0.114 & 0.788 & 0.275 \\
\hline Higher Heating Value & 0.351 & 0.183 & $0.000^{* *}$ & 0.107 & 0.058 & 0.735 & $0.006^{* *}$ \\
\hline
\end{tabular}

Density planting - D; Fertilizing level - F; Biomass fraction - B. $\mathrm{p}<.05\left({ }^{*}\right)$ and $\mathrm{p}<.01\left({ }^{* *}\right)$ significant by test $\mathrm{F}$.

Table 6

Simple effect of planting spacing and fertilization level on carbon content of Eucalyptus grandis $\times$ E. urophylla, at 2 years old.

\begin{tabular}{ll}
\hline Factors & Carbon (\%) \\
\hline Spacing $(\mathrm{m})$ & \\
$2.8 \times 0.5$ & $45.9 \mathrm{~B}$ \\
$2.8 \times 1.5$ & $46.2 \mathrm{~A}$ \\
Fertilization levels & \\
1 & $45.9 \mathrm{~B}$ \\
2 & $46.2 \mathrm{~A}$ \\
\hline
\end{tabular}

The means that do not differ from each other at the 0.05 significance level by Tukey's test are marked with the same letters in the same column.

\section{Ref. [30].}

Oxygen content showed a similar trend for both treatments studied. Thus, the triple interaction was not clearly defined, probably due to the strong effect of biomass fraction factor on the variance analysis. Significant differences occurred between the leaves and woody fractions.

There is a lack of information about mean values of chemical elements of ultimate composition from eucalypt plantations.
Usually, researchers have been considered for wood from conventional planted which carbon element represents $50 \%$ of dry matter biomass, but it is higher than determined for Eucalyptus SRC, about $44.3 \%, 44.7 \%$ and $49.1 \%$ for stem, branches and leaves fractions, respectively.

\subsubsection{Proximate analysis}

Fixed carbon content and volatile matter content behaved in opposing ways with respect to density of planting (Table 7). Further, as confirmed in the ultimate analysis, the fixed carbon followed the results of $C$ content, wherein higher content was found to at a lower density of planting.

Ash content, another important property, had a limiting effect on bioenergy use. It caused encrustations in the boilers when the biomass was used for direct combustion and greater damage in metallic equipment used in the production of briquettes or pellets. Ash content was higher for leaves fractions following branches and stem. Ash content of stem showed a reducing trend for increasing density of planting, as shown in Fig. 2. The fertilization effect showed different results for each treatment, and it was not possible to identify a regular behavior.
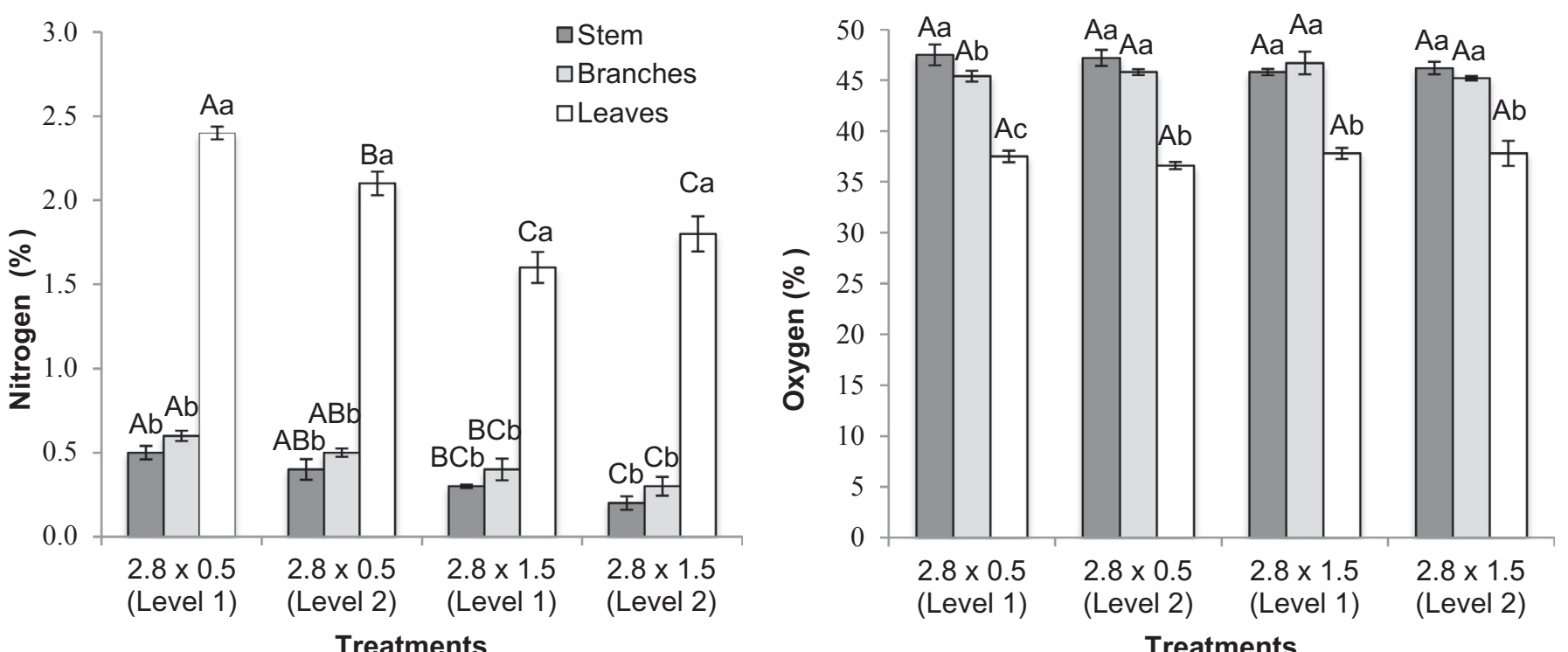

Treatments

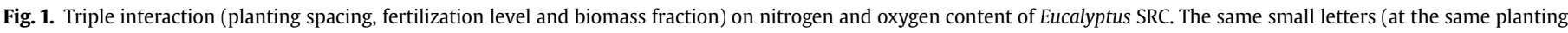
spacing and fertilization level) and the same capital letters (at the same biomass fraction) do not differ statistically by Tukey test ( $\alpha=0.05$ ). 
Table 7

Simple interaction of density planting on properties of Eucalyptus grandis $\times$ E. urophylla, at 2 years old.

\begin{tabular}{lll}
\hline Spacing $(\mathrm{m})$ & Properties & \\
\cline { 2 - 3 } & Fixed carbon & Volatile matter \\
\hline $2.8 \times 0.5$ & $16.2 \mathrm{~B}$ & $82.0 \mathrm{~A}$ \\
$2.8 \times 1.5$ & $17.2 \mathrm{~A}$ & $80.9 \mathrm{~B}$ \\
\hline
\end{tabular}

The means that do not differ from each other at the 0.05 significance level by Tukey's test are marked with the same letters in the same column.

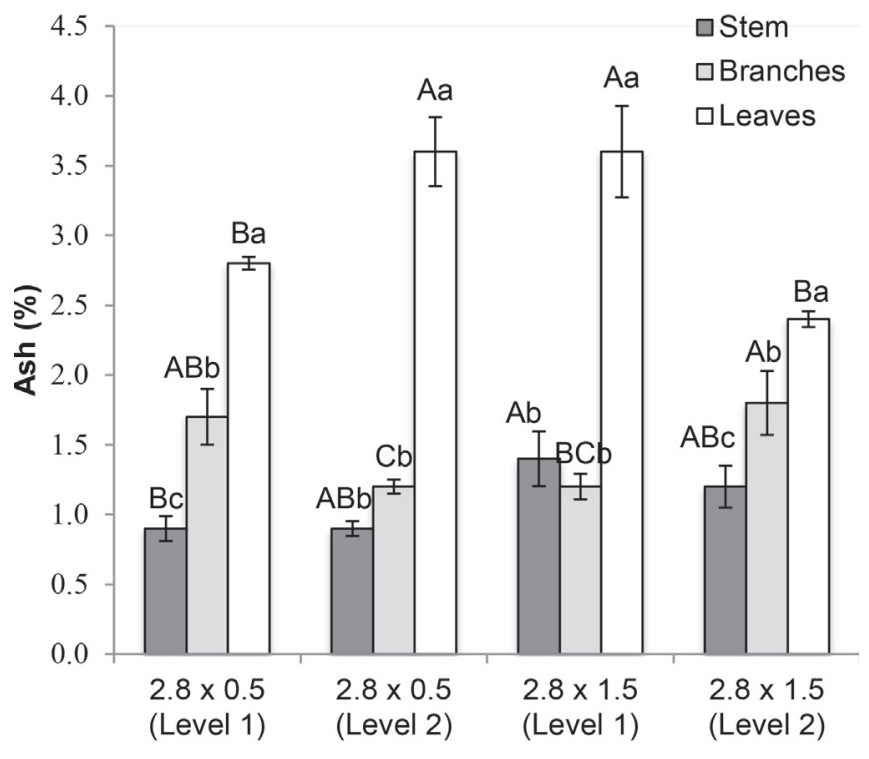

Treatments

Fig. 2. Triple interaction (planting spacing, fertilization level and biomass fraction) on Ash content of Eucalyptus SRC. The same small letters (at the same planting spacing and fertilization level) and the same capital letters (at the same biomass fraction) do not differ statistically by Tukey test $(\alpha=0.05)$.

\subsubsection{Structural chemical analysis}

Structural chemical composition of Eucalyptus biomass SRC was similar of softwood species as reported by Ref. [31].

Statistically significant difference for holocellulose and acidlignin content was observed (Table 8).

Holocellulose of branches fraction was influenced by the increasing density of planting. The acid-lignin content of leaves decreased with higher density of planting. These differences did not change the energy content among the treatments for the same biomass fraction.

If we consider only the use of stem fraction for other purposes as

Table 8

Double interaction of density planting and biomass fraction on holocellulose and lignin of Eucalyptus grandis $\times$ E. urophylla, at 2 years old.

\begin{tabular}{llll}
\hline Spacing $(\mathrm{m})$ & \multicolumn{2}{l}{ Biomass fraction } & \\
\cline { 2 - 4 } & Stem & Branches & Leaves \\
\hline Holocellulose $(\%)$ & & & \\
$2.8 \times 0.5$ & $82.4 \mathrm{Aa}$ & $69.8 \mathrm{Ab}$ & $33.8 \mathrm{Ac}$ \\
$2.8 \times 1.5$ & $80.6 \mathrm{Aa}$ & $67.1 \mathrm{Bb}$ & $36.0 \mathrm{Ac}$ \\
Lignin $(\%)$ & & & $18.1 \mathrm{Bb}$ \\
$2.8 \times 0.5$ & $21.5 \pm \mathrm{Aa}$ & $20.9 \pm \mathrm{Aa}$ & $22.2 \mathrm{Aa}$ \\
$2.8 \times 1.5$ & $21.7 \pm \mathrm{Aa}$ & $20.5 \pm \mathrm{Aa}$ & \\
\hline
\end{tabular}

The means that do not differ from each other at the 0.05 significance level by Tukey's test are marked with the same small letters (at the same line) and the same capital letters (at the same column) for each chemical property. paper and fiber industry, the increasing of density planting and fertilization have not effect on its structural chemical composition.

\subsubsection{Higher heating value}

As seen with oxygen content, the triple interaction in HHV only showed effect for the biomass fractions and did not vary among the treatments (Fig. 3). Hence, the planting density and fertilization level did not influence this property as verified by other authors for planted forests of Eucalyptus and other species in Brazil [32,33]. The small change of ultimate biomass quality with fertilization and density planting factors were not adequate to change the HHV. It is known that increase of HHV could be more associated with age of trees [34,35].

HHV of branches fraction were observed to be statistically similar to the stem fraction, whereas the leaves showed an average HHV $13.4 \%$ higher than the woody fraction. The greater HHV of leaves can be explained by the results of ultimate analysis (higher hydrogen content) and chemical analysis (higher total extractives content).

Eucalyptus biomass showed a better thermochemical performance for energy purposes (higher values of HHV and lower ash content) than poplar genotypes from short rotation forest [13]. However, this performance was worse when compared with new clones of willow cultivated in one and three year rotation cycles [36].

This paper complements the work published by Ref. [17], who studied the biomass and energy yield of Eucalyptus SRC in the same conditions presented in this experiment. Forest management is a tool to increase the efficiency and sustainable use of dedicated energy crops.

\section{Conclusions}

Fuel quality of biomass from a Eucalyptus short rotation coppice did not change with planting densities and fertilization levels. Only punctual and specific changes in some biomass properties were observed, but they did not promote effects on heating value.

For all properties evaluated statistically significant differences were found between the woody fractions (stem and branches) and leaves.

The findings can also be used by chemical and other industries associated with biorefinery processing to consider whole-tree

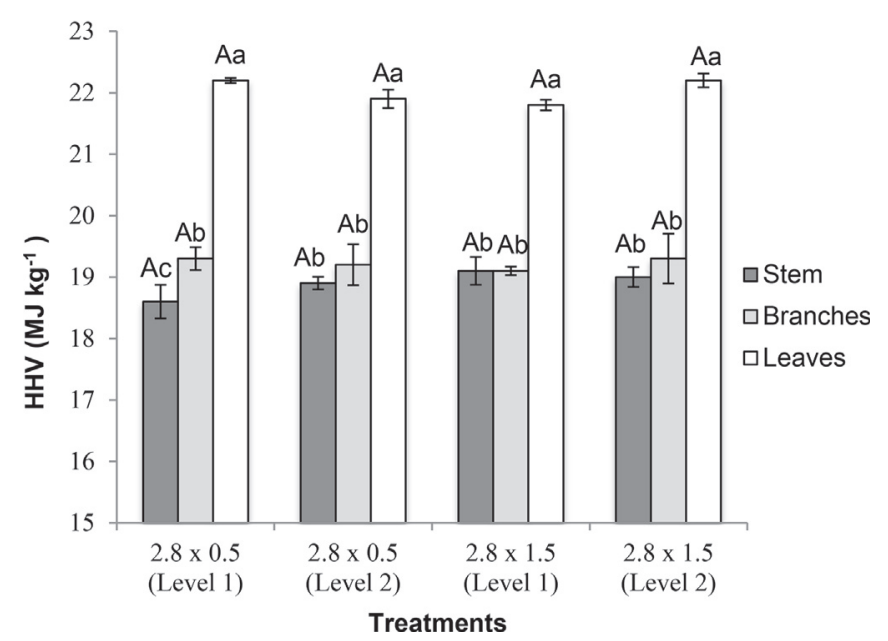

Fig. 3. Triple interaction (planting spacing, fertilization level and biomass fraction) on Higher Heating Value (HHV) of Eucalyptus SRC. The same small letters (at the same planting spacing and fertilization level) and the same capital letters (at the same biomass fraction) do not differ statistically by Tukey test $(\alpha=0.05)$. 
biomass for any application.

\section{Acknowledgments}

The authors would like to thank the financial support of Coordination for the Improvement of Higher Education Personnel (CAPES) and the Laboratory of Agroforest Biomass Bioenergy (LABB) at the Institute of Bioenergy Research (IPBEN).

\section{References}

[1] G.M. Souza, et al., The role of bioenergy in a climate-changing world, Environ. Dev. 23 (2017) 57-64.

[2] N. Scarlat, J.F. Dallemand, F. Monforti-Ferrario, V. Nita, The role of biomass and bioenergy in a future bioeconomy: policies and facts, Environ. Dev. 15 (2015) $3-34$.

[3] N.U. Aragon, M. Wagner, M. Wang, A.M. Broadbent, N. Parker, M. Georgescu, Sustainable land management for bioenergy crops, Energy Proc. 125 (2017) 379-388.

[4] T. Bridgewater, Biomass for energy, J. Sci. Food Agric. 86 (2006) 1755-1768.

[5] Y. Luo, V.K. Guda, E.B. Hassan, P.H. Steele, B. Mitchell, F. Yu, Hydrodeoxygenation of oxidized distilled bio-oil for the production of gasoline fuel type, Energy Convers. Manag. 112 (2016) 319-327.

[6] K.Y. Chiang, K.L. Chien, C.H. Lu, Characterization and comparison of biomass produced from various sources: suggestions for selection of pretreatment technologies in biomass-to-energy, Appl. Energy 100 (2012) 164-171.

[7] S.V. Vassilev, D. Baxter, L.K. Andersen, C.G. Vassileva, An overview of the chemical composition of biomass, Fuel 89 (2010) 913-933.

[8] H. Pereira, The importance of biomass structure and chemical composition for biorefineries, in: IUFRO Conference Division 5 Forest Products, Proceedings and Abstracts Book, 2012, pp. 57-62.

[9] A. Demirbas, Combustion characteristics of different biomass fuels, Prog. Energy Combust. Sci. 30 (2004) 219-230.

[10] L. Cuiping, W. Chuangzhi, Yanyongjie, H. Huang, Chemical elemental characteristics of biomass fuels in China, Biomass Bioenergy 27 (2004) 119-130.

[11] A. Sosa, M. Acuna, K. Mcdonnell, G. Devlin, Controlling moisture content and truck configurations to model and optimize biomass supply chain logistics in Ireland, Appl. Energy 137 (2015) 338-351.

[12] M.A. Brand, Energia de biomassa florestal (Book in Portuguese), Interciência, Rio de Janeiro, 2010.

[13] E. Monedero, J.J. Hernández, I. Cañellas, J.M. Otero, H. Sixto, Thermochemical and physical evaluation of poplar genotypes as short rotation forestry crops for energy use, Energy Convers. Manag. 129 (2016) 131-139.

[14] L. Rosso, G. Facciotto, S. Bergante, L. Vietto, G. Nervo, Selection and testing of Populus alba and Salix spp. as bioenergy feedstock: preliminary results, Appl. Energy 102 (2013) 87-92.

[15] P. Paris, L. Mareschi, M. Sabatti, A. Pisanelli, A. Ecosse, F. Nardin, et al., Comparing hybrid Populus clones for SRF across northern Italy after two biennial rotations: survival, growth and yield, Biomass Bioenergy 35 (2011) 1524-1532.
[16] S.P.S. Guerra, E.A. Garcia, K.P. Lanças, M.A. Rezende, R. Spinelli, Heating value of eucalypt wood grown on SRC for energy production, Fuel 137 (2014) $360-363$.

[17] H.J. Eufrade Junior, R.X. Melo, M.M.P. Sartori, S.P.S. Guerra, A.W. Ballarin, Sustainable use of eucalypt biomass grown on short rotation coppice for bioenergy, Biomass Bioenergy 90 (2016) 15-21.

[18] S.P.S. Guerra, G. Oguri, N.S. Ceragioli, R. Spinelli, Trade-offs between fuel chip quality and harvesting efficiency in energy plantations, Fuel 183 (2016) $272-277$.

[19] B.R. Vital, Método de determinação da densidade da madeira (in Portuguese), Boletim. Técnico. SIF 1 (1984) 1-21.

[20] ASTM E870-82, Standard Test Methods for Analysis of Wood Fuel, American Society for Testing and Materials, 2006.

[21] ASTM D1102-84, Standard Test Methods for Ash in Wood, American Society for Testing and Materials, 2007.

[22] ASTM E872-82, Standard Test Methods for Volatile Matter in the Analysis of Particulate Wood, American Society for Testing and Materials, 2006.

[23] TAPPI T222 om-11, Acid - Insoluble Lignin in Wood and Pulp, Technical Association of Pulp and Paper Industry, 2011.

[24] TAPPI T204 cm-07, Solvent Extractives of Wood and Pulp, Technical Association of Pulp and Paper Industry, 2007.

[25] ASTM E711-87, Standard Test Methods for Gross Calorific Value of Refusederived Fuel by the Bomb Calorimeter, American Society for Testing and Materials, 2004

[26] S.P.S. Guerra, G. Oguri, R. Spinelli, Harvesting Eucalyptus energy plantations in Brazil with a modified New Holland forage harvester, Biomass Bioenergy 86 (2016) 21-27.

[27] R. Spinelli, S. Ward, P. Owende, A harvest and transport cost model for Eucalyptus spp. fast-growing short rotation plantations, Biomass Bioenergy 33 (2009) 1265-1270.

[28] C. Sheng, J.L.T. Azevedo, Estimating the higher heating value of biomass fuels from basic analysis data, Biomass Bioenergy 28 (2005) 499-507.

[29] E.S. Lora, R.V. Andrade, Biomass as energy source in Brazil, Renew. Sust. Energy Rev. 13 (2009) 777-788.

[30] I. Obernberger, T. Brunner, G. Bärnthaler, Chemical properties of solid biofuels -significance and impact, Biomass Bioenergy 30 (2006) 973-982.

[31] A. Demirbas, Relationships between lignin contents and heating values of biomass, Energy Convers. Manag. 42 (2001) 183-188.

[32] E. Eloy, et al., Influence of spacing on energy characteristics of tree species on short rotation planting (in Portuguese), Rev. Árvore 38 (2014) 551-559.

[33] E.A. Garcia, S.P.S. Guerra, H.J. Eufrade Junior, C.A. Sansígolo, K.P. Lanças F.M. Yamaji, Chemical analysis of wood with bark in short rotation forestry systems (in Portuguese), Rev. Árvore 40 (2016) 163-171.

[34] R. Kumar, K.K. Pandey, N. Chandrashekar, S. Mohan, Effect of tree-age on calorific value and other fuel properties of Eucalyptus hybrid, J. Forensic Res. 21 (2010) 514-516.

[35] M. Lemenih, T. Bekele, Effect of age on calorific value and some mechanica properties of three Eucalyptus species grown in Ethiopia, Biomass Bioenergy 27 (2004) 223-232.

[36] M. Krzyżaniak, M.J. Stolarski, S. Szczukowski, J. Tworkowski, Thermophysical and chemical properties of biomass obtained from willow coppice cultivated in one- and three-year rotation cycles, J. Elem. (2015) 161-175. 